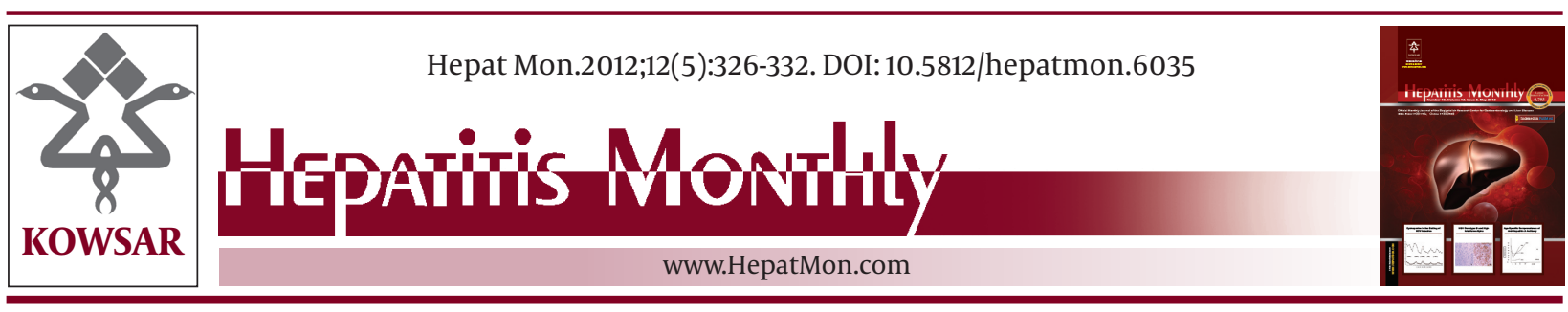

\title{
Age-Specific Seroprevalence of Anti-Hepatitis A Antibody Among 1-30 Years Old Population of Savadkuh, Mazandaran, Iran With Literature Review
}

\author{
Mohammed Jafar Saffar ${ }^{1^{*}}$, Omid Abedian ${ }^{1}$, Abolghasem Ajami ${ }^{2}$, Farshideh Abedian ${ }^{2}$, Araz \\ Mohammad Mirabi ${ }^{2}$, Ali-Reza Khalilian ${ }^{3}$, Hana Saffar ${ }^{4}$ \\ ${ }^{1}$ Pediatric Infectious Diseases Ward and Thalassemia Research Center, Bouali-Cina Hospital, University of Medical Sciences, Sari, IR Iran \\ ${ }^{2}$ Molecular and Cellular Biology Research Center, Department of Microbiology and Immunology, Mazandaran University of Medical Sciences, Sari, IR Iran \\ ${ }^{3}$ Department of Statistics, Mazandaran University of Medical Sciences, Mazandaran, Sari, IR Iran \\ ${ }^{4}$ Department of Pathology, Shariati Hospital, Tehran University of Medical Sciences, Tehran, IR Iran
}

\section{A R T I C L E I N F O}

Article type:

Original Article

Article history:

Received: 24 Dec 2011

Revised: 05 Apr 2012

Accepted: 21 Apr 2012

Keywords:

Hepatitis A Virus

Antibodies

Seroprevalence

Iran

\begin{abstract}
A B S T R A C T
Background: To determine age-specific seroprevalence rates of hepatitis A virus (HAV) immunoglobulin G (IgG) antibody in Savadkuh district, Mazandaran province, north of Iran, as well as to compare the collected data with earlier seroprevalence studies in the region and Iran in order to draw a proper epidemiological pattern for HAV infection in the country.

Objectives: This study aimed to assess an age-specific HAV seroprevalence among 1- to 30-yearold people in Savadkuh, a less developed district of Mazandaran province, north of Iran.

Patients and Methods: The study participants were 984 subjects who aged from one to 30 years and were residents of rural and urban areas of Savadkuh. They were selected using cluster sampling method and divided into five age groups: 1-2.9 (316 cases), 3-6.9 (254 cases), 7-10.9 (201 cases), 11-17.9 (115 cases), and 18-30 (98 cases). Anti-HAV antibody was measured by ELISA method. Seroprevalence rates among different age groups and their relationship to residency, educational levels of parents, water supply, and waste water disposal system was analyzed using chi-squared test.

Results: Overall seroprevalence rate was $19.20 \%$ with no significant difference between rural and urban residents. The seroprevalence rates increased significantly with age: from $5.7 \%$ in age group 1-2.9 year to $34.8 \%$ in adolescents, and to $68.4 \%$ among young adults $(P<0.0001)$; regardless of significant differences in educational levels among parents of residents in two areas it did not affect seroprevalence rates. Findings of this study and reviewing other reports from the region and the country suggest an epidemiological shift towards lower rates of antiHAV antibody seroprevalence.

Conclusions: It appears that anti-HAV antibody seroprevalence rate has been declining among Iranians and thereby more children would be susceptible to this infection. This would necessitate revising current strategies of preventative measures in Mazandaran and Iran.
\end{abstract}

Copyright $\odot 2012$ Kowsar Corp. All rights reserved.

- Implication for health policy/practice/research/medical education:

This Article presents an age-specific Seroprevalence rate of (HAV) (IgG Antibody)among people in such a less developed district of Iran; savadkuh and it declares getting some strategies in preventative measuring programs.

\footnotetext{
* Corresponding author: Mohammed Jafar Saffar, Pediatric Infectious Diseases Ward and Thalassemia Research Center, Bouali-Cina Hospital, Pasdaran Blvd., Mazandaran, Sari, IR Iran. Tel/Fax:+98-91512234506,

E-mail:Saffar@softhome.net
}

DOI:10.5812/hepatmon.6035

Copyright $\odot 2012$ Kowsar Corp. All rights reserved. 
- Please cite this paper as:

Saffar M.J, Abedian O, Ajami A, Abedian F, Mirabi AM, Khalilian AR, et al. Age-Specific Seroprevalence of Anti-Hepatitis Aantibody Among 1-30 Years-Old Population of Savadkuh, Mazandaran, Iran With Literature Review . Hepat Mon. 2012;12(5):326-32.DOI:10.5812/ hepatmon.603-5

\section{Background}

Hepatitis A virus (HAV) is an enterically- transmitted infection and leading cause of acute viral hepatitis throughout the world $(1,2)$. Epidemiologically, various geographical distribution of HAV infection exists that correlates closely with hygienic and sanitary conditions and other development indicators (3, 4). Clinical expression of HAV infection is highly age dependent and is minimal in children (1). Children play an important role in HAV transmission. Distribution of anti-HAV antibody seroprevalence over age groups can be used as a marker for HAV epidemiologic pattern and viral transmission through a community $(4,5)$. Declining seroprevalence rate in a population, particularly in children, is an indicator to reduced incidence of $\operatorname{HAV}(1,4)$. Many seroepidemiological findings revealed that a transition to lower rates of infection occurred in many hyperendemic countries within past two decades where their economic status improved $(1,6)$. In this situation, clinical manifestation of hepatitis A is likely to become a more serious problem in these countries. HAV infection could be prevented by immunization, and HAV vaccine may be used for pre-and post-exposure prophylaxis. Cost and feasibility are two major barriers to implementing HAV vaccination programs in these countries. Types of preventative strategies depend on epidemiologic characteristics of HAV infection and other vaccine-preventable diseases in any given country $(7,12)$.

In Iran, no proper periodic and age-specific seroprevalence data are available nationwide and exact epidemiological characteristics of HAV infection are unknown. Results of earlier seroprevalence studies on different populations in the country suggested a hyperendemic pattern (13-16). However, data collected in some recent studies demonstrated lower rates of infection especially among children $(17,21)$.

\section{Objectives}

This study aimed to assess an age-specific HAV seroprevalence among 1- to 30-year-old population in Savadkuh, a less developed district of Mazandaran province, north of Iran. Also, in order to determine epidemiological characteristics of HAV infection in Mazandaran and over the country and to plan the most appropriate preventative strategies, relevant articles previously issued in Iran were reviewed.

\section{Patients and Methods}

This cross-sectional seroepidemiological study was conducted in Savadkuh district, Mazandaran province, north of Iran. Savadkuh is a less developed mountainous area of Mazandaran with 70,000 inhabitants, equally distributed between rural and urban areas. Its population density is $33 / \mathrm{km}^{2}$ compared to $140 / \mathrm{km}^{2}$ in Sari district, the capital of province. A river passes through almost all parts of the district. Act of agriculture is the main occupation of residents. In four regions, urbanization infrastructures were encouraged and more people moved to these regions known as city of Savadkuh.

Target population consisted of healthy 1- to 30-year-old residents of Savadkuh. Random cluster sampling was used to enroll required samples, which was proportional to the number of inhabitants in each area. Sample size calculation was performed based on a prevalence of 0.20 $\%$ with 0.025 precision and $95 \%$ confidence interval which yielded a total 983 individuals. Epidemiologic data were collected from a questionnaire including age, sex, place of residence, educational levels of parents and adults, source of water supply, and method of waste water and sewage disposal. Based on education levels of adults and parents, the subjects were allocated into either of the following groups: I: illiterate-primary school, II: Junior secondary school, III: Senior secondary school and diploma, and IV: University educated levels. Also the participants were divided into five age groups: 1-2.9, 3-6.9, 7-10.9, 11-17.9, and 18-30 years. Study protocol was approved by the Ethics Committee of Mazandaran University of Medical Sciences. After written consent was obtained from parents and adults, blood samples were drawn. Sera were tested for anti-HAV antibodies using a qualitative ELISA method [HAV-Ab, DIA, Pro Diagnostic, Milano, Italy] according to the manufacturer's instructions. The results were reported as positive or negative.

A descriptive analysis was followed by univariate analysis Carrying out qui-squared test to compare various subgroups with a 5\% statistical significance levelOdds ratio and $95 \%$ confidence interval (CI) were calculated and presented for variables associated with risk of infections.

To determine epidemiological trends of HAV infection in Mazandaran and Iran, almost all relevant studies in Persian and English published in SID, Iran Medex, MEDLINE, Google, and Yahoo websites and containedkeywords HAV, Hepatitis A, HAV seroprevalence, HAV seroepidemiology, Mazandaran, and Iran were reviewed.

\section{Results}

All 984 individuals were enrolled in the study. The age groups and sex distribution, sites of residence, access to piped-water, and hygienic facility systems are shown in Table 1. As shown, there were no significant differences between rural and urban dwellers in regards to age, gender, 


\begin{tabular}{|c|c|c|c|c|c|}
\hline Variable $^{a}$ & Urban, No. (\%) & Rural, No. (\%) & Total, No. (\%) & Pvalue & OR $(95 \% \mathrm{CI})$ \\
\hline Enrolled Subjects & $506(51.4)$ & $478(48.6)$ & 984 & NS & - \\
\hline Male & $243(48)$ & $232(48.3)$ & $475(48.3)$ & NS & - \\
\hline \multicolumn{6}{|l|}{ Age groups, y } \\
\hline $1-2.9$ & 164 & 152 & $316(32.1)$ & NS & - \\
\hline $3-6.9$ & 128 & 126 & $254(25.8)$ & NS & - \\
\hline $7-10.9$ & 103 & 98 & $201(20.4)$ & NS & - \\
\hline $11-17.9$ & 59 & 56 & $115(11.7)$ & NS & - \\
\hline $18-30$ & 52 & 46 & $98(9.9)$ & NS & - \\
\hline Water supply system piped & (98) & (97) & & NS & - \\
\hline Educational levels ${ }^{\mathrm{b}}$ & 1064 & 1002 & & & \\
\hline Illiterate/kindergarten & 207 & 260 & 467 & 0.006 & $0.68(0.56-0.84)$ \\
\hline Junior school & 409 & 512 & 921 & $<0.0001$ & $0.59(0.50-0.71)$ \\
\hline High school/diploma & 371 & 214 & 585 & $<0.0001$ & $1.97(1.64-2.40)$ \\
\hline University & 77 & 16 & 93 & $<0.0001$ & $4.8(2.78-8.29)$ \\
\hline
\end{tabular}

a All families were used enclosed defecation system in both areas there was no centralized sewage disposal system

${ }^{b}$ Total numbers of 2066 is provided by 1968 parents $(984$ Couple) and 98 studied young adults $(18-30$ years old subjects $)(984 \times 2+98=2066)$.

\begin{tabular}{|c|c|c|c|c|c|}
\hline \multirow[t]{2}{*}{ Age Groups, y } & \multicolumn{2}{|c|}{ Positive HAV-Antibody, No(\%) } & \multirow[t]{2}{*}{ Pvalue } & \multirow[t]{2}{*}{ OR $(95 \% C I)^{a}$} & \multirow[t]{2}{*}{ Mean $^{b}$} \\
\hline & Urban $(n=506)$ & Rural $(n=478)$ & & & \\
\hline $1-2.9$ & $8(5.0)$ & $10(6.50)$ & 0.51 & $0.46(0.15,1.37)$ & 5.7 \\
\hline 3-6.9 & $11(8.6)$ & $12(9.50)$ & 0.74 & $0.86(0.37,1.97)$ & 9 \\
\hline $7-10.9$ & $19(18.4)$ & $22(22.40)$ & 0.48 & $0.80(0.43,1.51)$ & 20.4 \\
\hline $11-17.9$ & $20(34.0)$ & $20(35.7)$ & 0.83 & $0.99(0.53,1.84)$ & 34.8 \\
\hline $18-30$ & $35(67.3)$ & $32(69.6)$ & 0.81 & $0.93(0.57,1.54)$ & 68.4 \\
\hline Total & $93(18.4)$ & $96(20.1)$ & 0.4 & $0.89(0.56,1.23)$ & 19.20 \\
\hline
\end{tabular}

${ }^{\mathrm{a}}$ Seroprevalence Levels Were Increased Significantly With Age: PValue of 0.02, 0.01, 0.004, and ; Between age Group 1-2.9 Year to 18-30 Years Respectively.0.0001 ${ }^{\mathrm{b}}$ Mean stands for Mean Seroprevalence Rates for Each Age Group

and access to piped drinking water. In both areas (rural and urban), almost all households were employing enclosed defecation system but without any centralized waste water and sewage disposal systems. Table 1 presents educational levels of the sample. The educational levels of parents and adults among urban dwellers were significantly higher than those of rural counterparts. The overall anti-HAV seroprevalence rate was $19.20 \%$ with no statistically significant difference between urban and rural residents ( $18.4 \%$ vs. $20.1 \%, P=0.4, \mathrm{OR}=0.89$, CI: 0.65 $-1.23)$; Table 2. The seroprevalence rates increased significantly with age: from $5.7 \%$ in age group $1-2.9$ year to $34.8 \%$ in adolescents, and to $68.4 \%$ in young adults $(P<0.0001)$; Table 2. However, other variables including place of residence, educational levels, water supply, and waste water and sewage disposal systems did not influence anti-HAV antibody seroprevalence rates among rural and urban residents.

Reviewing published articles revealed that there were no proper periodic and age-specific seroepidemiological data available from Iran and most studies have reported hyperendemic patterns in their respective areas (Table 3). However, comparison between some similar older and more recent seroepidemiological studies from Mazandaran and Iran suggests a shifting pattern from high antiHAV antibody seroprevalence to lower rates of seroprevalence (Figure 1).

\section{Discussion}

Current findings showed that the majority (> $65 \%$ ) of older children and adolescents remained susceptible to HAV infection. Although the education levels (as a known risk factor for HAV infection) of parents and young adults living in urban areas were significantly higher than those of rural, the seropositive rates were not statistically different between rural and urban residents $(P=0.4)$. These discrepancies may be explained by higher educational levels of employees working in the urban infrastructures, otherwise most other important risk factors influencing HAV transmission in a community (access to clean water, waste and sewage disposal systems, living habits and culture) were similar between residents of two studied 


\begin{tabular}{|c|c|c|c|c|c|}
\hline & Study Place & Year & Age, $y$ & Prevalence, $\%$ & Study Subjects, No. \\
\hline \multicolumn{6}{|c|}{ Higher Rates of Endemicity } \\
\hline Shamsizadeh A, et al. (33) & Ahwaz & 2003 & $8-15$ & 81.2 & 800 \\
\hline Shavaki A, et al. (36) & Azarbaijan & 2006 & Adults & 96.5 & 200 \\
\hline Ramezani H, et al. (32) & Gazvin & 2008 & $17-60$ & 94.9 & 351 \\
\hline Merat S, et al. (30) & Golestan & 2006 & $18-65$ & 70-98.6 & 625 \\
\hline Ghadir MR, et al. (27) & Golestan & 2007 & $25-60$ & $70-99$ & 697 \\
\hline Mohammad Alizadeh AH, et al. (31) & Hamadan & 2004 & $10-50$ & $85-93$ & 171 \\
\hline Merat S, et al. (30) & Hormozgan & 2006 & $18-65$ & $70-96$ & 453 \\
\hline Saffar MJ, et al. (15) & Mazandaran & 1997 & $1-15$ & 74.7-90.6 & 716 \\
\hline Roushan MR, et al. (23) & Mazandaran & 2004 & $10-60$ & 59.4-97.5 & 392 \\
\hline Alborzi P, et al. (13) & Fars & 1996 & $2-14$ & $33-67$ & - \\
\hline Ehsanipour F, et al. (34) & Fars & 2008 & $18-40$ & 79.3-99 & - \\
\hline Khodaei E, et al. (14) & Tehran & 1996 & $2-14$ & $37-76$ & - \\
\hline Merat S, et al. (30) & Tehran & 2006 & $18-65$ & $65-97$ & 791 \\
\hline Ghorbani GA, et al. (28) & Tehran & 2006 & $19-22$ & 97.7 & 800 \\
\hline Alian S, et al. & Tehran & 2006 & 0.6 & $51.7-85$ & 1065 \\
\hline Ayatollahi J, et al. (26) & Yazd & 2000 & Adult & 89.5 & - \\
\hline Salehi M, et al. (16) & Zabol & 2000 & $1-15$ & 79.6-100 & 229 \\
\hline \multicolumn{6}{|c|}{ Lower Rates of Endemicity } \\
\hline Montazam S, et al. (21) & Azarbaijan & 2005 & $1-15$ & $1.2-27.2$ & 349 \\
\hline Ataei B, et al. (18) & Esfahan & 2005 & $6-65$ & $1-28.3$ & 816 \\
\hline Alian SH, et al. (17) & Mazandaran & 2007 & $1-25$ & $8.4-64.8$ & 1014 \\
\hline Saffar MJ, et al. (this study) & Mazandaran & 2010 & $1-30$ & $5.7-68.4$ & 984 \\
\hline Mehr AJ, et al. (20) & Tehran & 2002 & $0.6-15$ & $21.1-26.9$ & 1018 \\
\hline Sofian M, et al. (19) & Tehran & 2008 & $0.6-15$ & $36.8-52.4$ & 1056 \\
\hline Kazemi SA, et al. (29) & Zanjan & 2005 & $7-10$ & $42-45.4$ & 300 \\
\hline
\end{tabular}

areas.

The first published HAV epidemiological report from Mazandaran was an age-specific seroprevalence study in 1997 conducted among 1- to 15-year-old children in Sari, capital of Mazandaran province (15). In that study high prevalence rate (87\%) of HAV infection were reported:74.7 $\%, 86.7 \%$, and $90.6 \%$ in $1-5,5-10$, and $12-15$ years old subjects, respectively. Also, hyperendemic pattern was confirmed by other studies in some special high risk groups, older children, and adults in the region (22-24). However, results of a recent age-specific seroepidemiological study among 1-25-year-old population (17) demonstrated a lower infection rate especially among children, i.e. $8 \%, 20$ $\%$, and $64.8 \%$ in $<5,5-15$ and $15-25$ years old individuals, respectively. When this finding was compared with data reported by earlier published studies from the region (15, 22-24) (Figure 2A), results may suggest a declining rate of $\mathrm{HAV}$ infection as well as a transition to a less prevalent pattern of HAV infection. Our study findings also conforms to this concept and indicates an epidemiological shifting in Mazandaran province.
It is not easy to determine the epidemiological characteristics of the HAV infection in Iran due to lack of a nationwide database (HAV is not a reportable infection/ disease except in cases of outbreaks). WHO ranked Iran among areas of high prevalence of infection with a seroprevalence of $>90 \%$ at 10 years of age (6). Until 1996, there was only one study published from Iran about HAV infection characteristics (25). From 1997 to 2000, few scattered age-specific HAV seroprevalence studies were performed in some parts of the country (13-16). Results of these studies suggested high prevalence rates of infection: $80 \%, 74.7 \%, 33 \%$, and $37 \%$ seroimmunity levels in children $<5$ years old from Zabol (16) Sari (15), Tehran (14) and Shiraz (13), respectively. These rates were increased to $100 \%, 90.6 \%, 68 \%$, and $76 \%$ on the age of $10-15$ years in those cities, respectively. Later to 2000, several seroepidemiological studies were carried out in different populations living in some parts of the country (17-24, 26-33). Results, however, were not uniform. High prevalence rates have been reported from Ahwaz (33), Hamedan (31), Tehran $(14,28,34,35)$, Hormozgan (30), Golestan (17, 27), Qazvin 


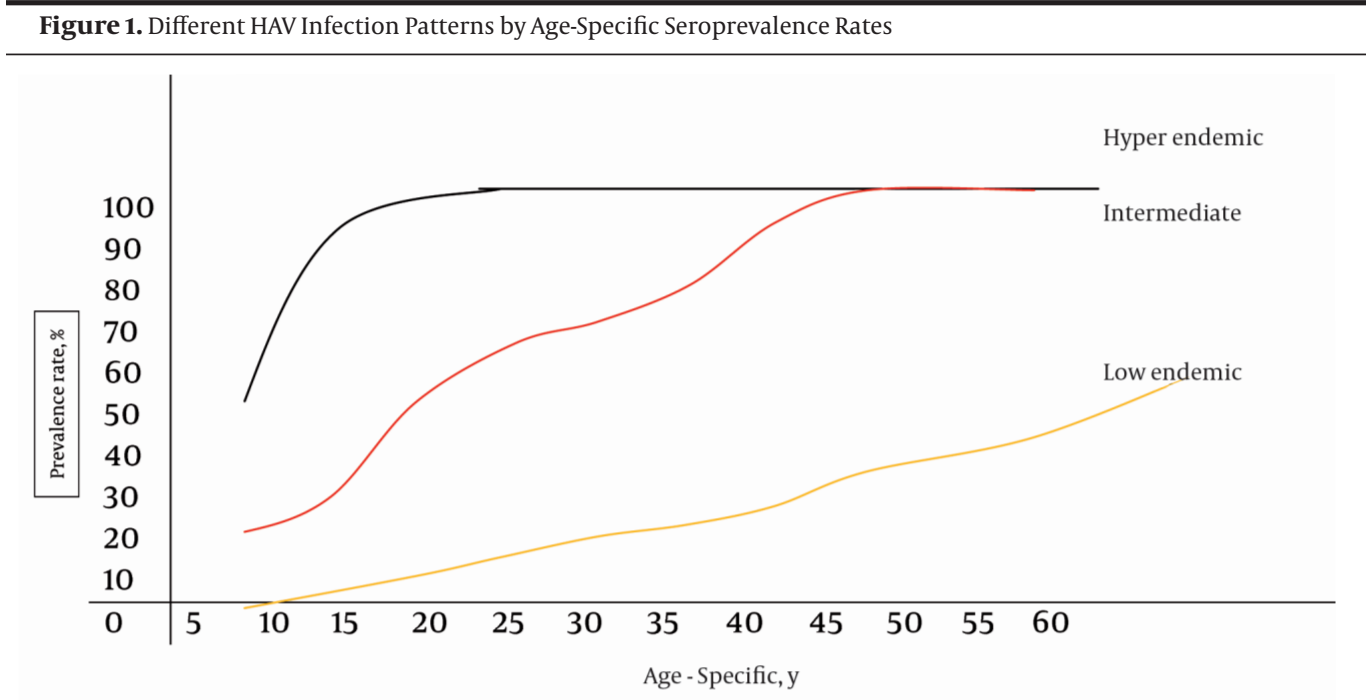

More than $90 \%, 50 \%$ and 5-10\% infection rates among $>15$ years old population indicate high, intermediate, and low endemicity, respectively.
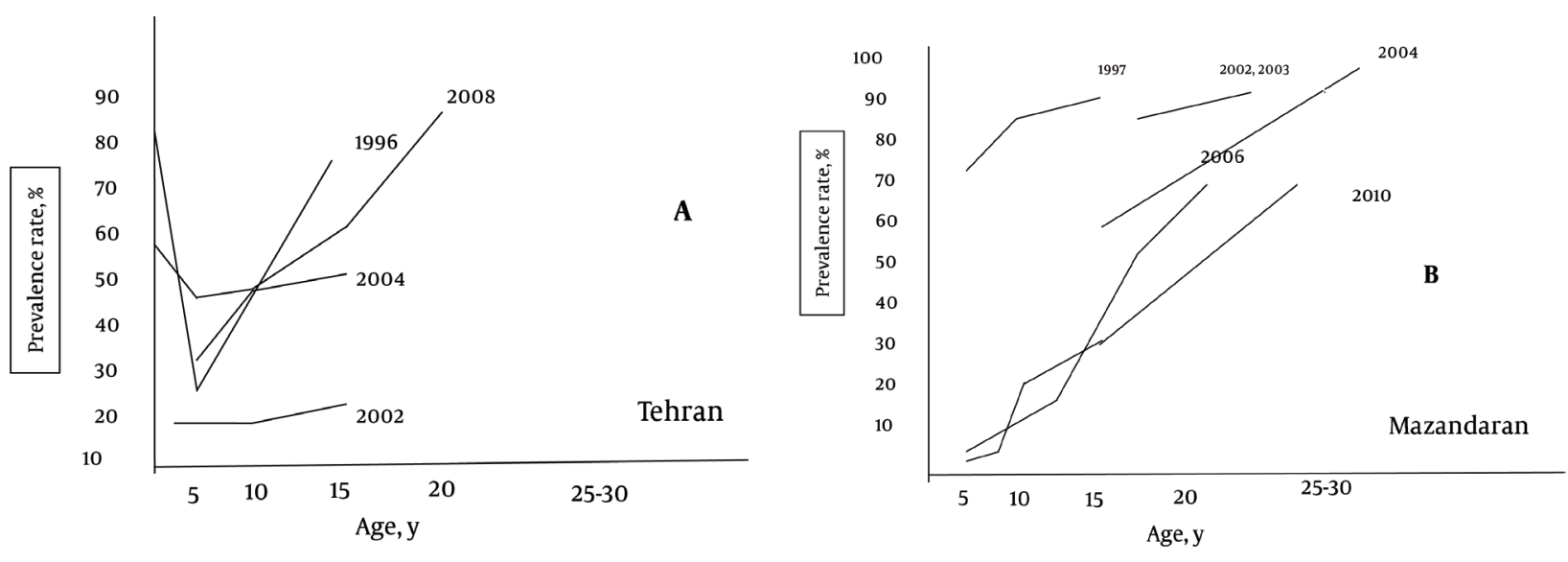

Figure 2. Age-Specific Seroprevalence of Hepatitis A Virus Infection in A) Tehran and B) Mazandaran From 1996 to 2010

(32), Shiraz (13, 35), Azarbaijan (36), Zanjan (29), and Yazd (26) provinces (Table 3). Other studies from Esfahan (18), Tehran, Azarbaijan (21), Mazandaran (17) demonstrated lower rates of infection especially among children (Table 3 , Figure 2). These results may implicate an epidemiological transition to lower rates of infection in some parts of the country.

During past two decades, many countries in the Middle East (37-41) and Asia $(42,43)$ experienced major improvement in socioeconomic status associated with urbanization, health education, access to clean drinking water, improved sanitation, and life style. Such improvements have been observed in Iran as well (44). This pattern may reduce the rates of HAV circulation in the community especially among children, and as a result more children and adolescents remained susceptible to infection dur- ing adulthood.

Decreasing prevalence of hepatitis A infection in children in Mazandaran and some other parts of Iran, demonstrated by some recent seroprevalence studies, designates HAV as a more likely etiologic agent of acute viral hepatitis in Iran. For instance, HAV was etiologic agent of $72 \%$ and $29.6 \%$ of acute severe clinical viral hepatitis represented in two university hospitals in Zahedan (45) and Mazandaran (46) during 2003-2004 and 2002-2007, respectively.

HAV is a preventable infection by immunization. Several HAV vaccines are available that are highly effective and provide long-lasting protection above 1-2 years of age, $(1,2,4,7,8,10,11)$. Cost and feasibility are two major barriers of public implementation of HAV vaccination $(4,7,8,47)$. Recommendation on usage of HAV vaccine 
varies considerably among countries. Guidelines from WHO (4), CDC (7), and experts $(8,10,11)$ on HAV vaccine emphasize on cost-benefit (47) and sustainable preventative strategies in the context of other priorities such as other diseases, and their morbidity and mortality in any given countries. Consequently, large-scale and public vaccination programs applicable in hyperendemic developing countries are not recommended. In hyperendemic countries that undergoes a lower rates of infection or intermediate endemicity, or where a large proportion of adolescents and adults remain susceptible to HAV infection and clinical hepatitis A represent a significant public health burden, large-scale childhood vaccination or targeted vaccination may be considered as a supplementary plan to health education and improved sanitation. As part of this decision process, the public health impact of HAV infection should be weighed against the impact of other vaccine-preventable infections and other preventative strategies.

In conclusion, according to the current findings and those obtained from literature review it seems that HAV epidemiology is changing in Mazandaran and Iran, and prevalence patterns are shifting to lower rates of endemicity. However, to make the most appropriate decision for pre-and post-exposure preventative strategies, periodic nationwide seroprevalence studies associated with active surveillance of clinical hepatitis A burden on public health are recommended. Until these happen, improving sanitation and health education along with targeted prophylaxis - if feasible - as a strategy for control HAV infection in Mazandaran and Iran seems to be more appropriate.

\section{Acknowledgements}

We would like to thanks parents and children for their participation in this study, staffs of primary health centers, and Dr. Enayati for his critical reading of the manuscript

\section{Authors' Contribution}

None declared.

\section{Financial Disclosure}

None declared.

\section{Funding/Support}

This project was funded by Deputy for Research of Mazandaran University of Medical Sciences

\section{References}

1. Fiore A, Bell B. Hepatitis A. In: Feigin RD, Cherry JD, editors. Textbook of pediatric infectious diseases. Philadelphia, PA: Saunders Elsevier; 2009. p. 3567.

2. Hollinger E, Emerson S. Hepatitis A. In: Hollinger FB, editor. Viral
Hepatitis. Philadelphia: Lippincott, Williams \& Wilkins; 2002. p. 240.

3. Jacobsen $\mathrm{KH}$, Koopman JS. The effects of socioeconomic development on worldwide hepatitis A virus seroprevalence patterns. Int J Epidemiol. 2005;34(3):600-9.

4. World Health Organization. Hepatitis A vaccine. [updated Feb 04 2000]; Available from: http://www.who.int/immunization/wer7505Hepatitis\%20A_Feb00_position_paper.pdf.

5. Victor JC, Surdina TY, Suleimeova SZ, Favorov MO, Bell BP, Monto AS. The increasing prominence of household transmission of hepatitis A in an area undergoing a shift in endemicity. Epidemiol Infect. 2006;134(3):492-7.

6. Jacobsen $\mathrm{KH}, \mathrm{Koopman}$ JS. Declining hepatitis A seroprevalence: a global review and analysis. Epidemiol Infect. 2004;132(6):100522.

7. American Academy of Pediatrics, Pickering LK. Hepatitis A. In: American Academy of Pediatrics, Pickering LK, editors. Red Book: 2009 Report of the Committee on Infectious Diseases. Elk Grove Village, IL: American Academy of Pediatrics; 2009. p. 984.

8. Ferreira CT, da Silveira TR. Viral hepatitis prevention by immunization.J Pediatr (Rio J). 2006;82(3 Suppl):S55-66.

9. Victor JC, Monto AS, Surdina TY, Suleimenova SZ, Vaughan G, Nainan OV, et al. Hepatitis A vaccine versus immune globulin for postexposure prophylaxis. N Engl J Med. 2007;357(17):1685-94.

10. Fiore AE, Feistone SM, Bell BP. Hepatitis A vaccine. In: Stanley AP, Paul AO, Walter AO, editors. Vaccines. Philadelphia, Pa.: Saunders/ Elsevier; 2008. p. 177-205.

11. Koff RS. Review article: vaccination and viral hepatitis - current status and future prospects. Aliment Pharmacol Ther. 2007;26(10):1285-92.

12. Wasley A, Samandari T, Bell BP. Incidence of hepatitis A in the United States in the era of vaccination. JAMA. 2005;294(2):194201.

13. Alborzi P, Alborzi A, Boub R, Amoateng Y. Hepatitis A seroprevalence in Iranian children: implications for postexposure prophylaxis. 41st annual meeting of IDSA; 2003 October 9-12; San Diego. 2003.

14. Khodaei E. Hepatitis A seroepidemiology in Tehranian children less than 14 years old. 7th Congress of Infectious Diseases and Tropical Medicine; 1998; Babolsar. 1998. p. 37.

15. Saffar MJ, Hemmatabady M. [Hepatitis A Seroepidemiology among 1-15 years old children in Sari Iran 1997]. Mazandaran Univ Med Sci J.1999;9(22-23):1-6.

16. Salehi M, Sanei Moghaddam E. [Seroepidemiology of Hepatitis A in population under 30-years-old in rural areas of Zabol]. Guil Univ Med Sci J. 2001;10(37-38):26-9.

17. Alian SH, Farhanian A, Noorani S. Seroepidemiological evaluation of HAV among 1-25 years old general population in Sari of Mazandaran provice [These for Medical Doctor]. Sari: Mazandaran University Medical Sciences; 2006.

18. Ataei B, Javadi AA, Nokhodian Z, Kassaeian N, Shoaei P, Farajzadegan Z, et al. HAV in Isfahan province: a population-based study. Trop Gastroenterol. 2008;29(3):160-2.

19. Sofian M, Aghakhani A, Farazi AA, Banifazl M, Etemadi G, AzadArmaki S, et al. Seroepidemiology of hepatitis A virus in children of different age groups in Tehran, Iran: implications for health policy. Travel Med Infect Dis. 2010;8(3):176-9.

20. Mehr AJ, Ardakani MJ, Hedayati M, Shahraz S, Mehr EJ, Zali MR. Age-specific seroprevalence of hepatitis A infection among children visited in pediatric hospitals of Tehran, Iran. Eur J Epidemiol. 2004;19(3):275-8.

21. Montazam S, Kafshounchi M, Tanoumand A. Age-specific prevalence of antibodies to hepatitis A in rural and urban population of Malekan city. [Med Sci J Islamic Azad Univ - Tehran Med Branch]. 2007;7(1):41-4.

22. Saffar MJ, Jooyan AR, Mahdavi MR, Khalilian A. [Seroprevalence of hepatitis A, B, and C and hepatitis B vaccination status among health care workers in Sari-Iran, 2001]. Mazandaran Univ Med Sci J. 2005;15(47):67-77.

23. Roushan MR, Bijani A, Sagheb R, Jazayeri O. Prevalence of hepatitis A IgG in individuals with chronic hepatitis B infection in 
Babol. East Mediterr Health J. 2007;13(5):1108-13.

24. Saffar MJ, Mousa-dost R, Mahdavi MR, Koosarian M. [Seroepidemiology of hepatits A virus infection among Sari thalasemic patients with chronic liver disease : Implication for HAV vaccination]. J Mazandaran Univ Med Sci. 2005;15(46):45-55

25. Farzadegan H, Shamszad M, Noori-Arya K. Epidemiology of viral hepatitis among Iranian population--a viral marker study. Annals of the Academy of Medicine, Singapore. 1980;9(2):144.

26. Ayatollahi J, Hadinadoshan H. Evaluation of anti- HAV antibody in secondary school students of Yazd city. Shahid Sadoughi Univ Med. 2001;9(4):87-90.

27. Ghadir MR, Ansari R, Amjadi H, Sheykh-Esmaeili F, Vaez Javadi m. Hepatitis A and E in the east of Golestan province. J Med Council of IRI. 2007;25(1):34-8.

28. Ghorbani GA, Alavian SM, Assari S. Seroepidemiology of Hepatitis A Virus in Iranian Soldiers in 2006: Do They Need Vaccination. Hepat Mon. 2007;7(1):7-9.

29. Kazemi SA, Mahram M, Koosha A, Amirmoghaddami HR. Seroprevalence of Hepatitis A in 7-10 year-old children. Iran J Ped. 2007;17(1):47-51.

30. Merat S, Rezvani H, Nouraei M, Abolghasemi H, Jamali R, AminiKafiabad S, et al. Seroprevalence and risk factors of hepatitis $A$ Prevalence and risk factors for HCV infection in Iran: a population-based study. Arch Iran Med. 2010;13(2):99-104.

31. Mohammad Alizadeh AH, Ranjbar M, Keramat F, Mamani M, Rezazadeh M. Frequency of hepatitis A virus antibodies in patients with Hepatitis B and hepatitis C in Iran. J Pazoohesh in Pezeshki. 2007;31(1):39-42.

32. Ramezani H, Bozorgi SH, Nooranipour M, Mostajeri A, KargarFard $\mathrm{H}$, Molaverdikhani S, et al. Prevalence and risk factors of hepatitis A among blood donors in Qazvin, central Iran. Singapore Med J. 2011;52(2):107-12.

33. Shamsizadeh Hayatdavoodi A, Makvandi M. [Survey of hepatitis A virus immunity among children aged 10-15 years in Ahwaz City by ELIZA method]. Ahwaz Univ Med Sci. 2004;1(44):21-6.

34. Ehsanipour F, Shayanfar N, Azimi M. [Seroprevalence Of Hepatitis A Infection In Children Referred To Rasoul Akram Hospital]. Razi J Med Sci (J Iran Univ Med Sci). 2006;13(51):25-31.

35. Taghavi SA, Hosseini Asl MK, Talebzadeh M, Eshraghian A. Seroprevalence study of hepatitis A virus in Fars province, southern
Iran. Hepat Mon. 2011;11(4):285-8.

36. Shavakhi A, Somi MH, Farhang S, Majidi G, Majidi T, Pouri AA. [Prevalence of hepatitis A in Iranian patients with chronic liver disease]. Iran J Clin Infect Dis. 2008;3(4):189-92.

37. Sidal M, Ünüvar E, Oğuz F, Cihan C, Önel D, Badur S. Age-specific seroepidemiology of hepatitis A, B, and E infections among children in Istanbul, Turkey. Euro J Epid. 2001;17(2):141-4.

38. Tufenkeji H. Hepatitis A shifting epidemiology in the Middle East and Africa. Vaccine. 2000;18:S65-S7.

39. Almuneef MA, Memish ZA, Balkhy $\mathrm{HH}$, Qahtani M, Alotaibi B, Hajeer A, et al. Epidemiologic shift in the prevalence of Hepatitis A virus in Saudi Arabia: a case for routine Hepatitis A vaccination. Vaccine. 2006;24(27-28):5599-603.

40. Battikhi MN, Battikhi EG. The seroepidemiology of Hepatitis A virus in Amman, Jordan. New Microbiol. 2004;27(3):215-20.

41. Sacy RG, Haddad M, Baasiri G, Khoriati A, Gerbaka BJ, Abu-Elyazeed R. Hepatitis a in Lebanon: a changing epidemiological pattern. Am J Trop Med Hyg. 2005;73(2):453-6.

42. Chatproedprai S, Chongsrisawat V, Chatchatee P, Theamboonlers A, Yoocharoen P, Warinsathien P, et al. Declining trend in the seroprevalence of infection with hepatitis A virus in Thailand. Ann Trop Med Parasitol. 2007;101(1):61-8.

43. Kim YJ, Lee HS. Increasing incidence of hepatitis A in Korean adults. Intervirology. 2010;53(1):10-4

44. Movahedi M, Haghdoost AA, Pournik O, Hajarizadeh B, Fallah MS Temporal variations of health indicators in Iran comparing with other Eastern Mediterranean Region countries in the last two decades. J Public Health (Oxf). 2008;30(4):499-504.

45. Salahei M, Ansari Moghaddam A, Sanei Moghaddam E, Khosrav S, Hajibeigi B, Alavian SM. [The epidemiological pattern of acute viral hepatitis in Tehran and Zahedan: A comparison study]. Gastroenterol Hepatol Bed Bench. 2010;3(1):33-6.

46. Baba Mahmoodi F, Baba Mahmoodi AAR, Valipour R, Delavarian L. [Prevalence OF Viral Hepatitis and Clinical Epidemiology and Prognosis of Hepatitis A In Adult Patients Admitted to Razi University Hospital Iran 2003-2008]. J Mazandaran Univ Med Sci. 2010;20(77):2-9.

47. Rosenthal P. Cost-effectiveness of hepatitis A vaccination in children, adolescents, and adults. Hepatology. 2003;37(1):44-51. 